\title{
ABNORMAL SPECIFIC DYNAMIC ACTION OF PROTEIN, GLUCOSE, AND FAT ASSOCIATED WITH UNDERNUTRITION

\author{
By EDWARD H. MASON
}

With the Techncal Assistance of ELEANOR HILL aND DOROTHY CHARLTON

(From the University Clinic, The Royal Victoria Hospital, and the Medical Department, McGill University, Montreal)

(Received for publication April 18, 1927)

\section{INTRODUCTION}

Rubner (1) in 1902 developed the conception of a specific dynamic action for protein, glucose, and fat. He thought that the extraheat produced during the digestion and oxidation of protein, glucose, or fat was derived from the intermediary metabolism of the foodstuffs themselves. He also showed that this extra heat was waste heat, and that it could not be utilized by the organism for the production of muscular work.

That this original conception of Rubner was in part incorrect has been shown by more recent studies. Lusk and his associates have proved that, in the case of protein, the process of deamination and urea formation have no effect upon heat production (2). They have also presented experiments (3) showing no specific dynamic action in dogs with the amino acids, glutamic and aspartic, while glycocoll and alanin in a normal dog caused a marked increase in heat production. Furthermore, Lusk (4) demonstrated that the specific dynamic action of glycocoll was independent of its oxidation. Grafe (5) in 1915 , in a series of experiments upon rabbits, dogs, and men, obtained evidence that glutamic acid, asparagin, phenylalanine, ammonium chloride and acetamid as well as glycocoll and alanin caused an increase in heat production. More recently Atkinson and Lusk (6) presented a critical review of Grafe's work, and reported experiments with asparagin, aspartic and succinic acids, ammonium citrate and acetamid, finding in no case evidence of a specific dynamic action. 
In 1918 Burge and Neill (7) (8) reported that the increase in heat production associated with the eating of foods was accompanied by an increase of catalase in the blood, an enzyme which was able to liberate oxygen from hydrogen peroxide. After a meat meal the increase in catalase was most marked. They found that glycocoll and alanin produced an increase in catalase while glutamic acid did not. Subsequently, Burge (9) conducted experiments to see if aspartic and succinic acids, acetamid and asparagin, would produce an increase in the blood catalase. His conclusion was that the introduction of small amounts, 5 grams per kilo of body weight, of glutamic, aspartic, and succinic acids, asparagin, and acetamid produced no increase in catalase, while large amounts, 14 grams per kilo of body weight, did produce such increase. This work has not been confirmed.

More recently Aub, Everett and Fine (10) have reported observations upon the intravenous adminstration of glycocoll in urethanized and decerebrate cats. Glycocoll given intravenously in 5 and 10 gram doses in four experiments showed no specific dynamic action in urethanized animals while in four experiments upon decerebrate cats with an average weight of 3 kilos, glycocoll given intravenously in 5-gram doses gave an average increase of heat production of 29.9 per cent.

These facts tend to indicate that the specific dynamic action of protein, contrary to Rubner's original conception, is not inherent in the oxidation of the protein molecule itself. Certain amino acids, while undergoing their own intermediary metabolism, apparently stimulate the tissue cells to produce more heat. The observations of Grafe, contradictory to Lusk's experiments, were not subsequently confirmed by Lusk. Since the report of Burge and Neill that the eating of foods was accompanied by an increase of blood catalase has not been confirmed, its significance cannot be evaluated. The fact that Aub, Everett and Fine have reported the absence of specific dynamic action for glycocoll in urethanized animals may lead to observations that will throw light on the fundamental nature of the process.

The mechanism of the extra heat production after the ingestion of glucose is thought to depend upon its combustion. If the ingested 
glucose is converted first into glycogen Johansson (11) reported that there was no extra heat produced. Glucose, ingested by a diabetic and excreted in the urine, causes no increased heat production. That absorption and circulation of glucose is without effect upon heat production was clearly shown by Lusk (12) in phloridzinized dogs. Lusk ascribed the specific dynamic action of glucose as being due accordingly to an interrelationship between the circulating glucose and the metabolizing cells themselves, that is "the metabolism of carbohydrate plethora."

In the case of fat the fundamental mechanism of the extra heat production would appear to be of the same nature as that of glucose. It depends directly upon the quantity of oxidizing fat, is parallel to the level of the blood fat, and likewise has been termed by Lusk, "the metabolism of fat plethora".

\section{EXPERIMENTAL STUDIES}

In this communication are reported six cases of disturbed nutrition, the onset and course of which in five was associated with definite subjective symptoms of ill health. In these five cases there was a progressive loss of weight. Studies upon the specific dynamic action of protein, glucose, and fat in all cases showed varying degrees of abnormality. Regulation of the diet in accordance with the altered specific dynamic action resulted in a satisfactory gain in weight in four of the cases. In the other two, sufficient time has not elapsed to make a definite statement. When an improved level of nutrition had been established, in the three cases studied a marked change in specific dynamic action had taken place.

In the determination of the specific dynamic action three types of meals were used: a "protein" meal containing 150 or 200 grams of lean beef as stated; a "carbohydrate" meal of 100 grams of glucose dissolved in $300 \mathrm{cc}$. of lemonade which contained $60 \mathrm{cc}$. of lemon juice; and a "fat" meal composed of $200 \mathrm{cc}$. of 20 per cent cream, 40 grams of butter, and 30 grams of toast.

The case reports of these six cases are appended. 


\section{ANALYTICAL METHODS AND CALCULATIONS}

Throughout the experimental periods all the cases were hospitalized. Only in those cases where stated was a known intake of food maintained. Between experiments there was no restriction of activity. All basal metabolic rate determinations were conducted with the patient strictly controlled as to the "basal" state. The prolonged respiratory experiments to determine the rise in heat production after the "protein," "glucose" and "fat" meals extended over three to six hours as stated. A preliminary "basal" hour was observed in each experiment at the end of which the patient ate the meal. With the subject remaining at rest in bed, expired air was collected in Douglas bags during the final ten minutes of the "basal" hour, and during the final ten minutes of each subsequent period. The volume and temperature of the expired air was determined by a wet meter, gas analysis being completed in duplicate on the Henderson machine. Fluid intake was maintained constant at $200 \mathrm{cc}$. per hour. Urine was collec ted each hour and total nitrogen determined by the Kjeldahl-Günning technique ${ }^{\circ}$ The non-protein respiratory quotients were calculated in the usual way. The caloric value of oxygen for calculation of the non-protein calories was obtained from the tables of Zuntz and Schumberg as modified by Lusk (13). The protein calories were figured from the urinary nitrogen employing the factor 26.51. The calculation of the percentage increase of heat production above the "basal" level in the experimental periods was figured from the total calories produced.

The meat given as the "protein" meal was analyzed for its nitrogen content each day, and its protein content obtained by using the factor 6.25 . Since the $60 \mathrm{cc}$. of lemon juice given with the "glucose" meal contained only three grams of carbohydrate as determined by analysis it was neglected in the calculations. In the case of the "fat" meal the fat content of the cream was also determined. For the calculation of the ingestion of protein calories the factor 4.1 and for the glucose calories the factor 3.74 were used.

In those few observations where the basal metabolic rate was determined by oxygen consumption a Sanborn-Benedict closed system machine was used.

The Sage Foundation standards of normal basal metabolism were employed throughout.

\section{THE NORMAL SPECIFIC DYNAMIC REACTION (AVERAGE)}

Most studies upon specific dynamic action of the food factors have been conducted upon adult individuals or upon dogs. Whether the increase of heat production after protein, glucose, and fat ingestion in the growing child is different from that of the adult is not known. This point is of especial importance in this series of six cases as five of them varied from 14 to 18 years of age.

Since the time of Rubner it has been known that the specific dynamic 
action of protein was the greatest. He (1) calculated that the increased heat production for every 100 calories of protein ingested or metabolized was 30.9 calories for meat protein and in the case of a phloridzinized animal 31.9 calories for body protein. Exact data obtained by indirect calorimetry has been reported by Carpenter and Benedict (14) on the normal individual after 200 and 150 grams of beef. In two cases after 200 and 196 grams of beef containing 9.18 and 9.01 grams of nitrogen respectively the total increment increase of heat in three hours amounted to 25 and 28 calories. In one case after 150 grams of beef containing 8.0 grams of nitrogen there were 24 calories of extra heat produced in three hours. Aub and DuBois (15) have reported two experiments with 600 and 662 grams of beef, containing 23.7 and 24.1 grams of nitrogen respectively in which the extra heat produced from 1.5 to 5.5 hours after eating the meat amounted to 12.8 and 11.6 per cent of the energy value of the ingested protein calories. Several other authors have published data after the ingestion of mixed meals which is very difficult to use for comparative purposes. An outstanding point in such a survey is the marked variation in different individuals even with the same intake. This is marked even in the standard work of Carpenter and Benedict.

In the case of glucose Carpenter and Benedict (14) reported a total increment increase of heat of 18 calories in 4 hours after 100 grams plus one lemon. This was the average of ten observations. Gephart and DuBois (16) using 100 grams of glucose plus $10 \mathrm{cc}$. of lemon juice reported an increase of 25.9 calories in 3 hours in one case, and an increase of 22.46 calories in 4 hours in another. Thus glucose when given in 100 gram doses causes an extra production of heat to the extent of about 6 per cent of its energy value.

Studies upon pure fat by Magnus-Levy (17) indicated that the extra heat production amounted to about 2.5 per cent of the total calories ingested. Carpenter and Benedict (14) reported that it was about 3 per cent of the fat calories ingested.

For the purpose of controlling the reported observations like experiments were conducted upon five hospital patients who presented conditions unlikely to affect specific dynamic action. This data is tabulated in tables 1, 2, and 3, and composite curves of the average percentage rise in heat production shown graphically in chart 1 . In 


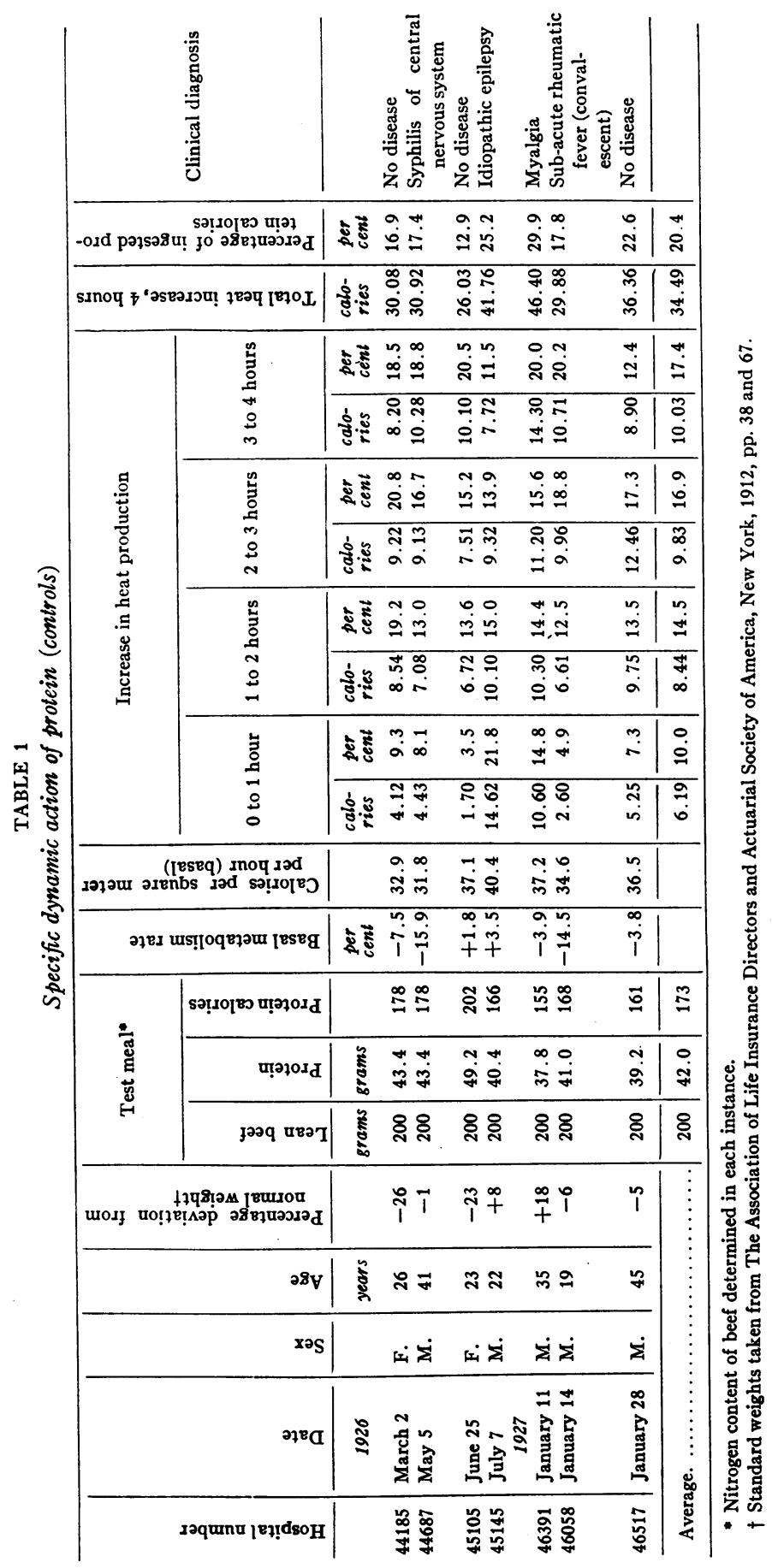




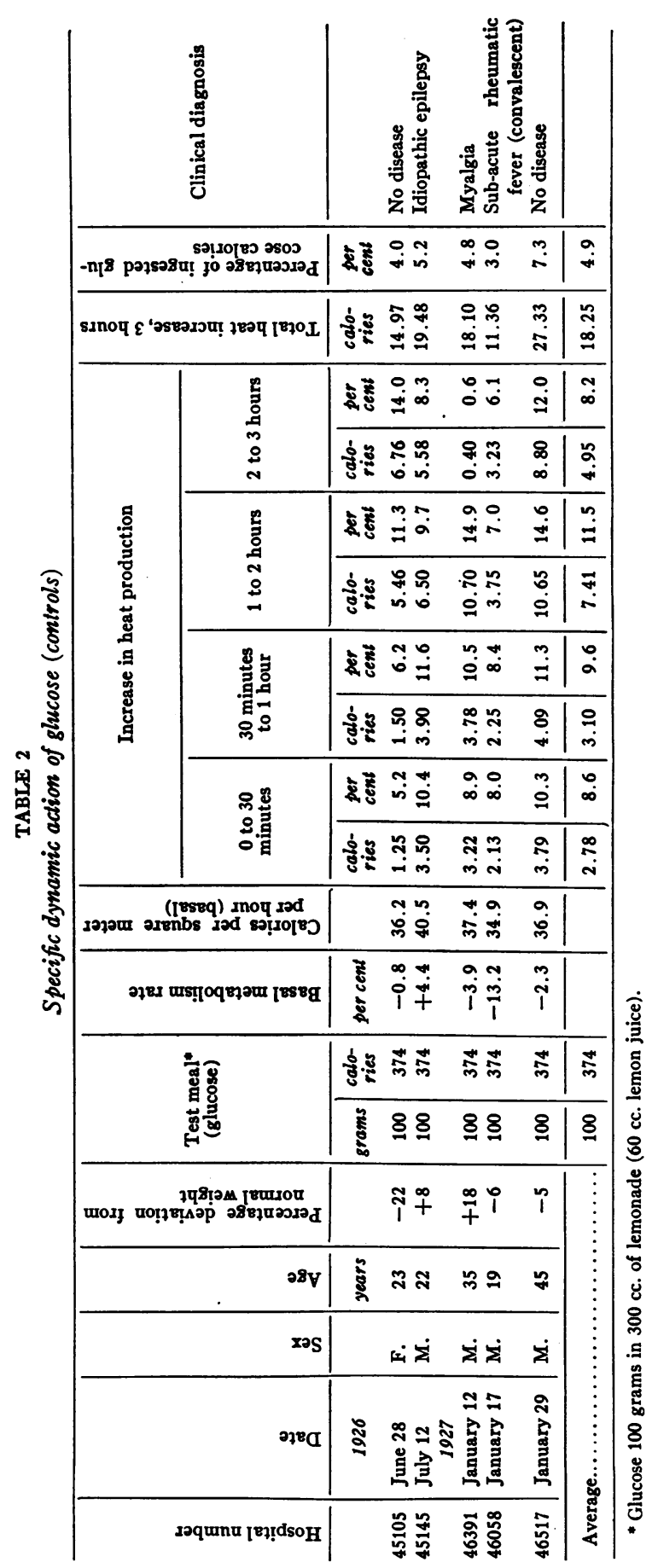




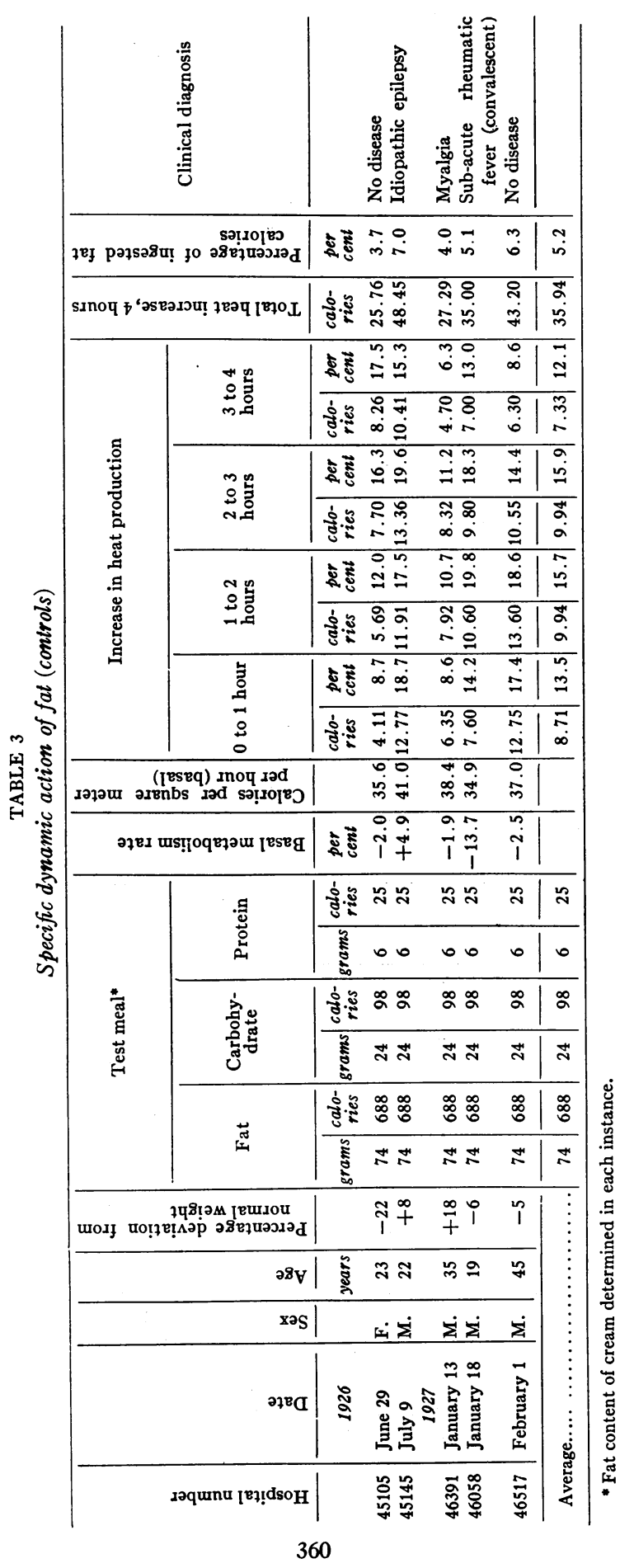


the "protein" group, table 1, two additional cases have been included. Unfortunately the age periods of these individuals does not correspond to that of the cases of undernutrition. It will also be noted that their weights in three instances deviated considerably from the average for the given sex, age, and height. In all except two cases, nos. 44687

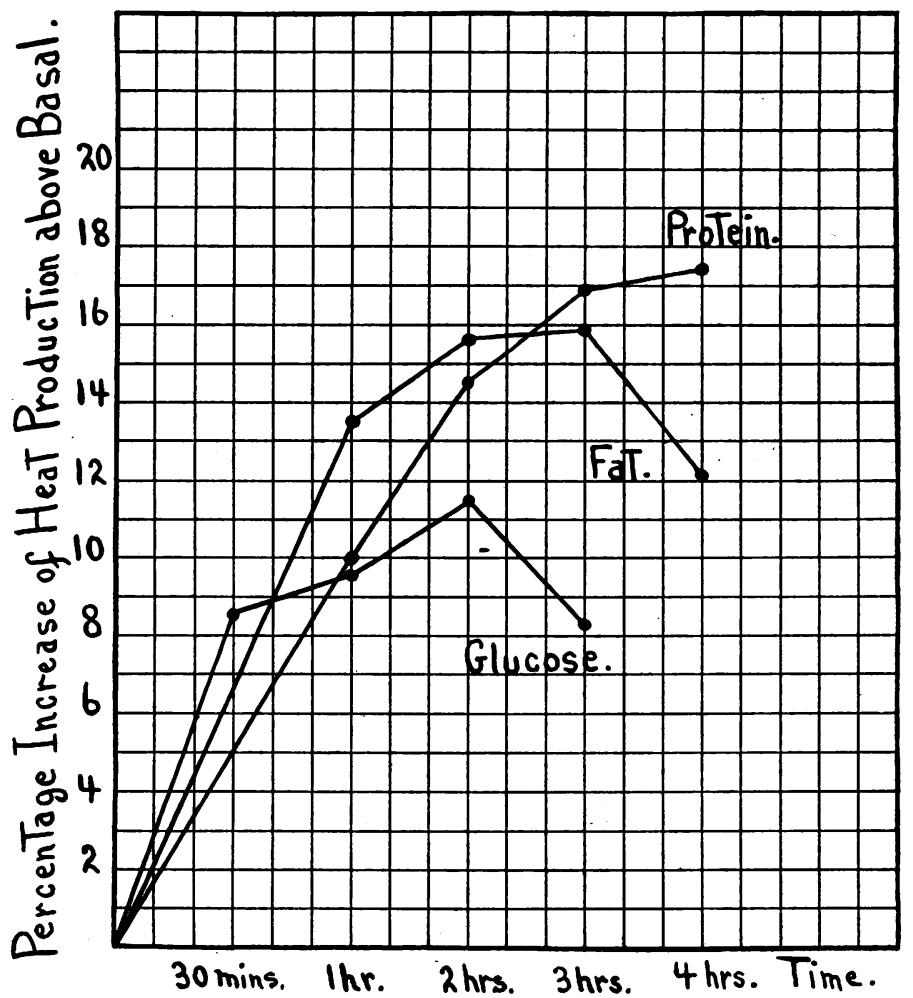

Chart 1. Composite Curves of the Percentage Increase of Heat Production above the Basal Level in the "Control" Cases after the "Protein," "Glucose" and "Fat" Meals

and 46058, the basal metabolic rates fell within the accepted normal variation of \pm 10 per cent. In those two there was no determined reason why it should be a little below normal. In no case was it below minus 16 per cent. In all these cases uniformity of basal heat production upon different days was obtained, well shown in the five 
cases upon whom each of the three types of experiments were carried out. This uniformity of the basal heat production lends accuracy to the experimental periods.

The meals used were the same as in most of the experiments with the cases of undernutrition. The "protein" meal contained 200 grams of lean beef, the "glucose" meal 100 grams of glucose plus $60 \mathrm{cc}$. of lemon juice, and the "fat" meal $200 \mathrm{cc}$. of 20 per cent cream, 40 grams of butter, and 30 grams of toast.

In the case of the protein "controls" some individual irregularity was found in the time of the maximum percentage increase of heat production. This was most marked in no. 45145 , who showed the greatest increment caloric increase in the first hour. The average results of the seven experiments present a uniform percentage increase of heat production which reaches a plateau between the fourth and and the fifth hours. The average total increment increase of heat production was 34.49 calories in 4 hours, individual variations ranging from 26.03 to 46.40 calories. The average total increment increase of heat production in 4 hours was 20.4 per cent of the ingested protein calories.

The individual variations in the five glucose "control" observations may be due to variations in the patients' glycogen reserves. When these are depleted no rise in the respiratory quotient may follow the ingestion of glucose, as originally noted by Zuntz and Mering (18). This has been considered to be due to storage as glycogen, and Johansson (11) showed that if ingested glucose was first converted into glycogen no extra heat was produced. The total caloric increment increase in 3 hours averaged 18.25 calories, which was 4.9 per cent of the total ingested energy intake.

Since the rise in heat production after the ingestion of fat is supposed to be dependent upon oxidation, so the individual variations as seen in the fat "controls" may in part be explained. The average percentage hourly increment increase presented a smooth curve. The average total increment heat increase in 4 hours was 35.94 calories, being 5.2 per cent of the ingested fat calories. Since the meal contained 98 carbohydrate calories, and 25 protein calories, the discrepancy between the usual accepted percentage caloric increase and the ingested fat calories, namely 3 per cent, can be partly explained. 


\section{CASES REPORTED}

State of nutrition of cases. As will be seen from table 4, four of the six cases were females, and two males. In all except one instance, case III, they had not attained adult development. Height was approximately normal for age except in case II where it was excessive. Upon admission they were all markedly underweight for their age and height. The degree of undernutrition varied from 21 to 40 per cent below the average for the given sex, age and height. The loss of weight prior to admission in the first five cases varied from 5 to 28 kilos. Case VI had no history of a recent loss of weight, but he had been unable to maintain a normal level of nutrition since eight years

TABLE 4

Cases of undernutrition

\begin{tabular}{|c|c|c|c|c|c|c|c|c|c|}
\hline \multirow{2}{*}{$\begin{array}{c}\text { Serial } \\
\text { number }\end{array}$} & \multirow{2}{*}{ Sex } & \multirow{2}{*}{ Age } & \multirow{2}{*}{$\begin{array}{c}\text { Weight } \\
\text { on admis- } \\
\text { sion }\end{array}$} & \multirow{2}{*}{ Height } & \multirow{2}{*}{$\begin{array}{l}\text { Loss of } \\
\text { weight }\end{array}$} & \multirow{2}{*}{$\begin{array}{c}\text { Percent- } \\
\text { age } \\
\text { under } \\
\text { weight* }\end{array}$} & \multirow{2}{*}{$\begin{array}{l}\text { Average } \\
\text { basal } \\
\text { metabo- } \\
\text { lism rate }\end{array}$} & \multicolumn{2}{|c|}{ Blood pressure } \\
\hline & & & & & & & & Systolic & $\overline{\text { Diastolic }}$ \\
\hline & & years & kilos & $\mathrm{cm}$. & kilos & per cent & per cent & $m m . \mathrm{Hg}$ & $m m . \mathrm{Hg}$ \\
\hline I & F. & 14 & 27.5 & 146 & 18 & 33 & -31 & 90 & 60 \\
\hline II & M. & 14 & 41.6 & 169 & 5 & 24 & -15 & 98 & 64 \\
\hline III & F. & 31 & 34.1 & 158 & 23 & 40 & -26 & 92 & 56 \\
\hline IV & F. & 18 & 43.8 & 162 & 18 & 21 & -27 & 100 & 65 \\
\hline V & F. & 15 & 44.8 & 166 & 28 & 21 & -15 & 110 & 60 \\
\hline VI & M. & 14 & 32.1 & 149 & $t$ & 23 & -4 & 112 & 70 \\
\hline
\end{tabular}

* Standard weights taken from Association of Life Insurance Directors and Actuarial Society of America, New York, 1912, pp: 38 and 67.

$\dagger$ No special loss of weight but failure to gain.

of age. In the first five cases the basal metabolic rates were appreciably below normal, reaching the low figure in case I of minus 31 per cent. With these low levels of basal metabolism the findings characteristic of myxedema were completely absent. Blood pressures were not significant.

Photographs of cases I, II, III, and VI taken upon admission are appended which give one a visual conception of the degree of undernutrition. A second photograph of case $I$ is also shown, taken in August, 1926, after nutrition had been re-established.

The uniformity of the basal metabolic rate in all cases and its parallelism in cases I and III to an improved state of nutrition is 
TABLE 5

Cases of undernutrition-basal metabolism

\begin{tabular}{|c|c|c|c|c|c|c|}
\hline Date & 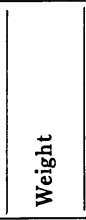 & 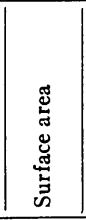 & $\begin{array}{l}\dot{0} \\
\stackrel{\alpha}{ }\end{array}$ & 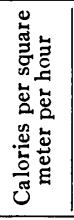 & 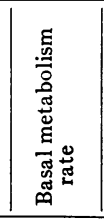 & Remarks \\
\hline \multicolumn{7}{|c|}{ Serial I } \\
\hline \multirow{2}{*}{\multicolumn{7}{|c|}{ First Admissio }} \\
\hline & & & & & & \\
\hline January 9, 1926. & 28.29 & 1.100 & & 29.2 & $2-32.1$ & $\mathrm{O}_{2}$ consumption only \\
\hline January 11. & 28.52 & 1.100 & & 26.6 & $6|-38.1|$ & $\mathrm{O}_{2}$ consumption only \\
\hline January $16 .$. & 28.97 & 1.110 & 0.825 & 28.8 & -33.0 & Good coöperation \\
\hline January 18. & 29.09 & 1.115 & 0.836 & 29.2 & -32.1 & Good coöperation \\
\hline January 19. & 29.09 & 1.115 & 0.837 & 28.9 & $\mid-32.6$ & Good coöperation \\
\hline January 22 . & 29.62 & 1.120 & 0.844 & 29.4 & -31.6 & Good coöperation \\
\hline January 25. & 30.00 & 1.125 & $0.815 \mid$ & 30.8 & $\mid-28.2$ & Good coöperation \\
\hline January 27. & 29.74 & 1.120 & 0.849 & 28.9 & -32.7 & Good coöperation \\
\hline January 28. & 30.00 & 1.125 & 0.866 & 32.0 & -25.7 & Tired \\
\hline February $1 .$. & 30.45 & 1.130 & 0.815 & 31.1 & -27.6 & Tired \\
\hline February $10 \ldots$ & 31.36 & 1.150 & 0.868 & 29.4 & -31.6 & Good coöperation \\
\hline \multicolumn{2}{|l|}{ Average. } & & 0.837 & 29.5 & -31.4 & \\
\hline \multicolumn{7}{|l|}{ Second admission: } \\
\hline August 11, 1926. & 40.45 & 1.290 & 0.782 & 35.0 & -18.5 & Good coöperation \\
\hline August 12 . & 40.45 & 1.290 & 0.788 & 35.3 & -18.0 & Good coöperation \\
\hline August 13.. & 40.45 & 1.290 & 0.780 & 35.2 & -18.1 & Good coöperation \\
\hline \multicolumn{2}{|l|}{ Average. } & & 0.783 & 35.2 & -18.2 & \\
\hline \multicolumn{7}{|l|}{ Third admission: } \\
\hline February 5, 1927 & 42.5 & 1.320 & 0.773 & 34.7 & $|-19.3|$ & Good coöperation \\
\hline \multicolumn{7}{|c|}{ Serial II } \\
\hline \multicolumn{7}{|l|}{ First admission } \\
\hline March 22, 1926. & 41.59 & 1.445 & & 38.6 & -16.0 & $\mathrm{O}_{2}$ consumption only \\
\hline March 23 & 40.90 & 1.435 & $|0.779|$ & 40.2 & -12.6 & Good coöperation \\
\hline March 24.. & 41.59 & 1.445 & 0.780 & 38.5 & -16.2 & Good coöperation \\
\hline March 25... & 41.36 & 1.440 & 0.800 & 40.4 & -12.2 & Good coöperation \\
\hline \multicolumn{2}{|l|}{ Average. . } & & 0.786 & 39.4 & -14.2 & \\
\hline \multicolumn{7}{|l|}{ Second admission: } \\
\hline February 21,1927 & 47.27 & 1.575 & 0.879 & 38.3 & -16.6 & Good coöperation \\
\hline February 22 . & 46.81 & 1.570 & 0.781 & 38.6 & -16.0 & Good coöperation \\
\hline February $23 .$. & 45.90 & 1.560 & 0.835 & 37.9 & -17.7 & Good coöperation \\
\hline \multicolumn{2}{|l|}{ Average. } & & 0.831 & 38.3 & $|-16.8|$ & \\
\hline
\end{tabular}


TABLE 5-Continued

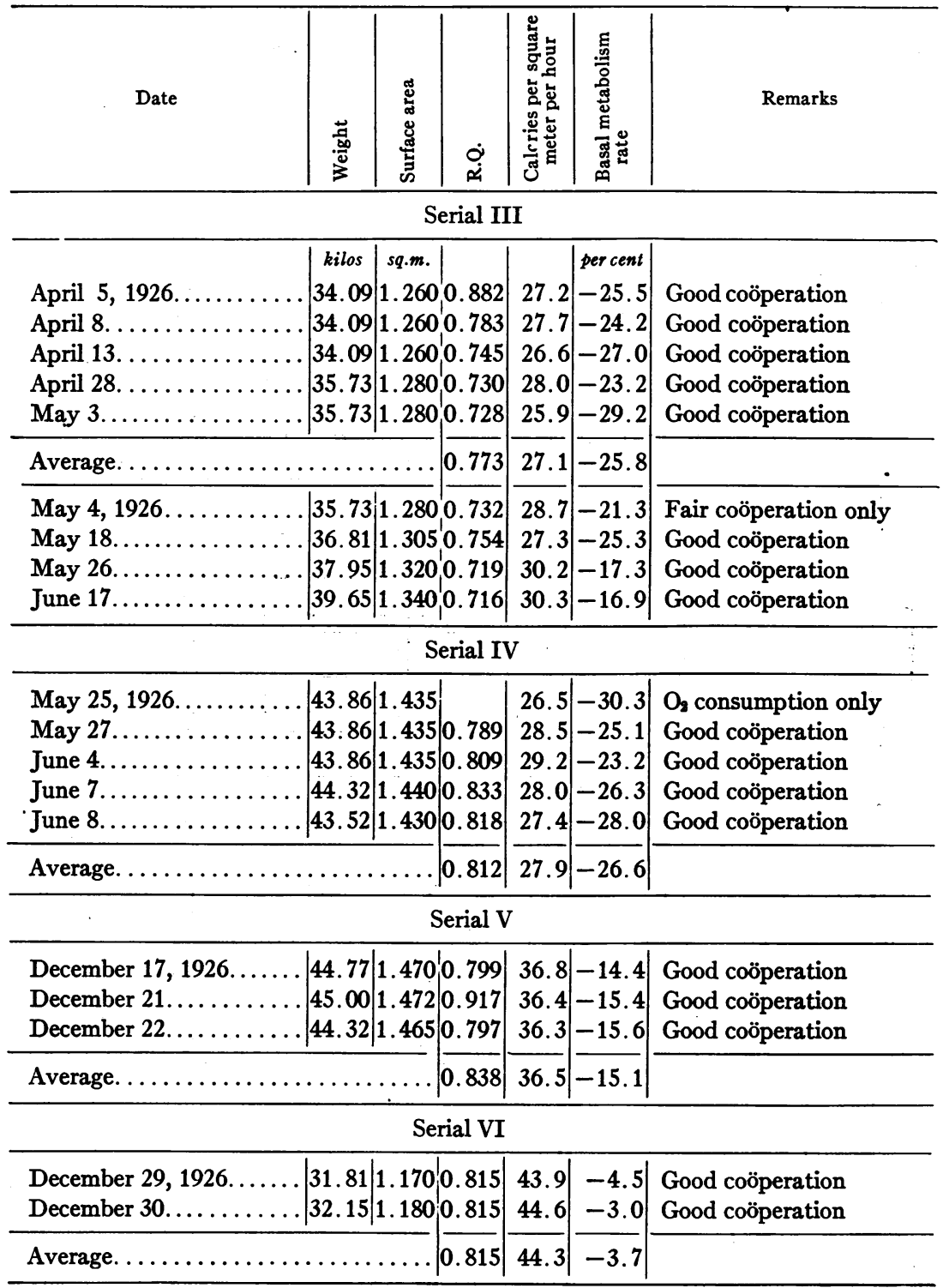




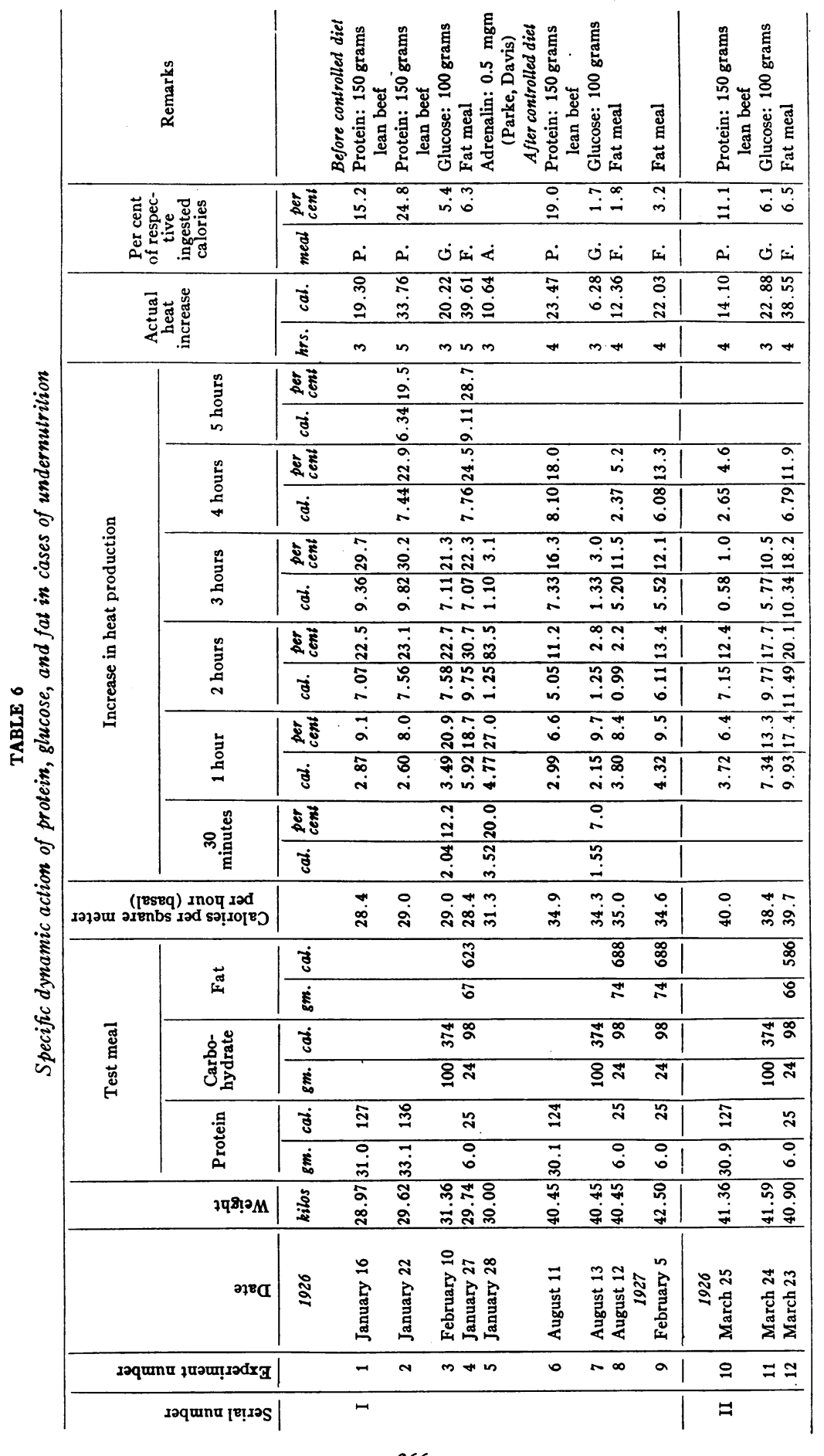




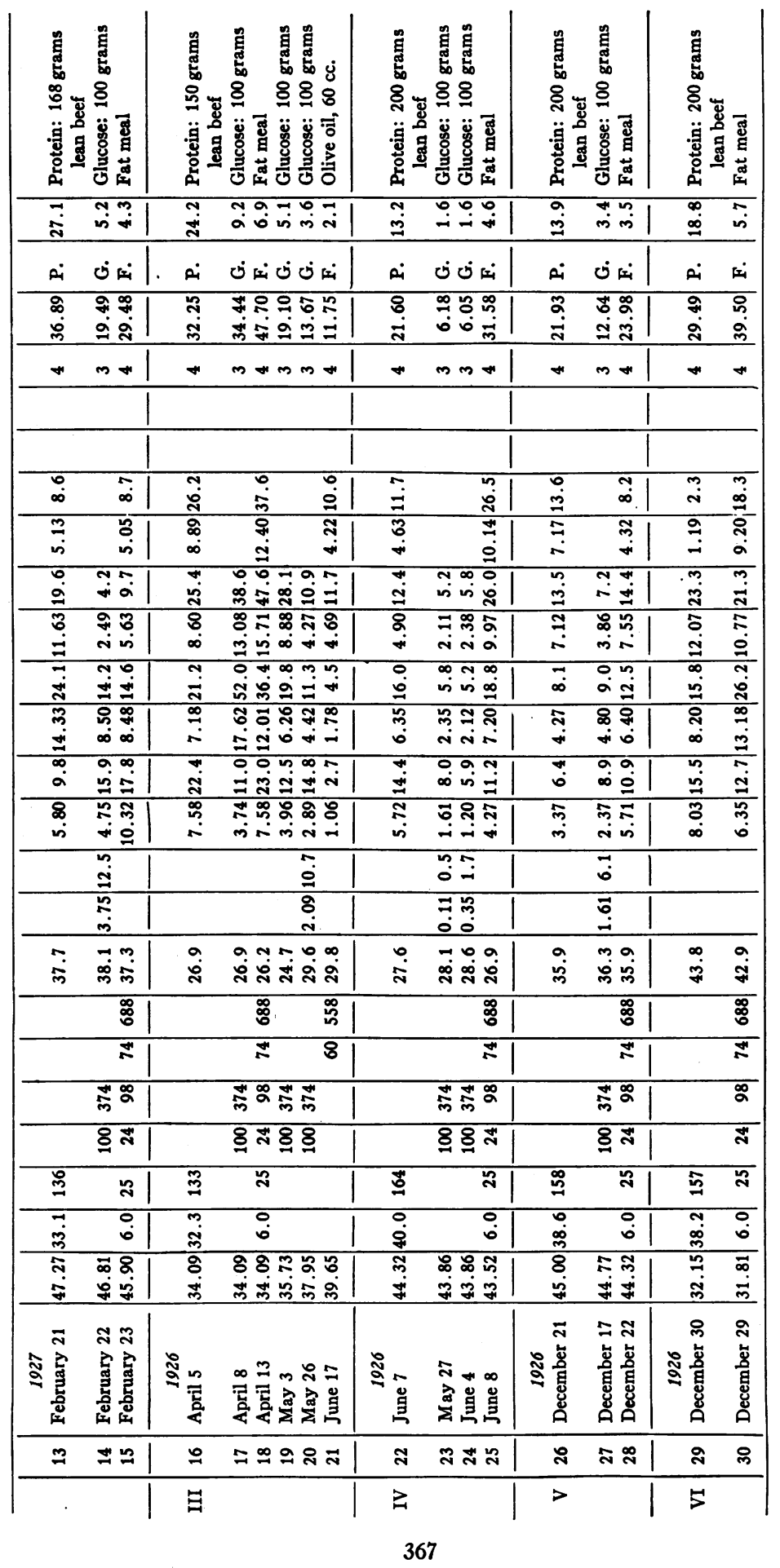




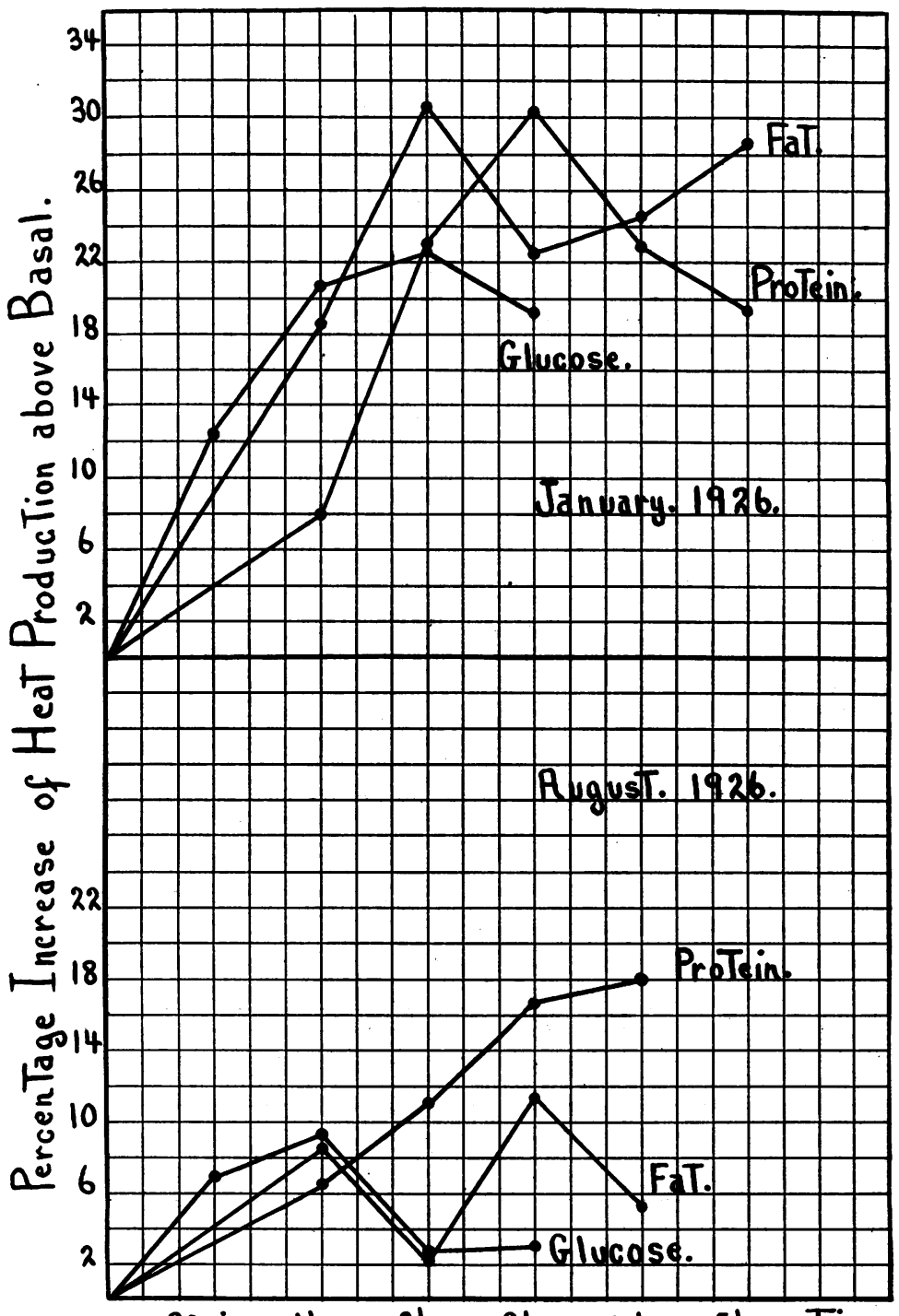

Chart 2. Case I. Curves of the Percentage Increase of Heat Production above the Basal LeVel after the "Protein," "Glucose," AND "FAT" MEALS

In January, 1926, the weight was approximately 28 kilos, and in August, 1926, 40.45 kilos. 


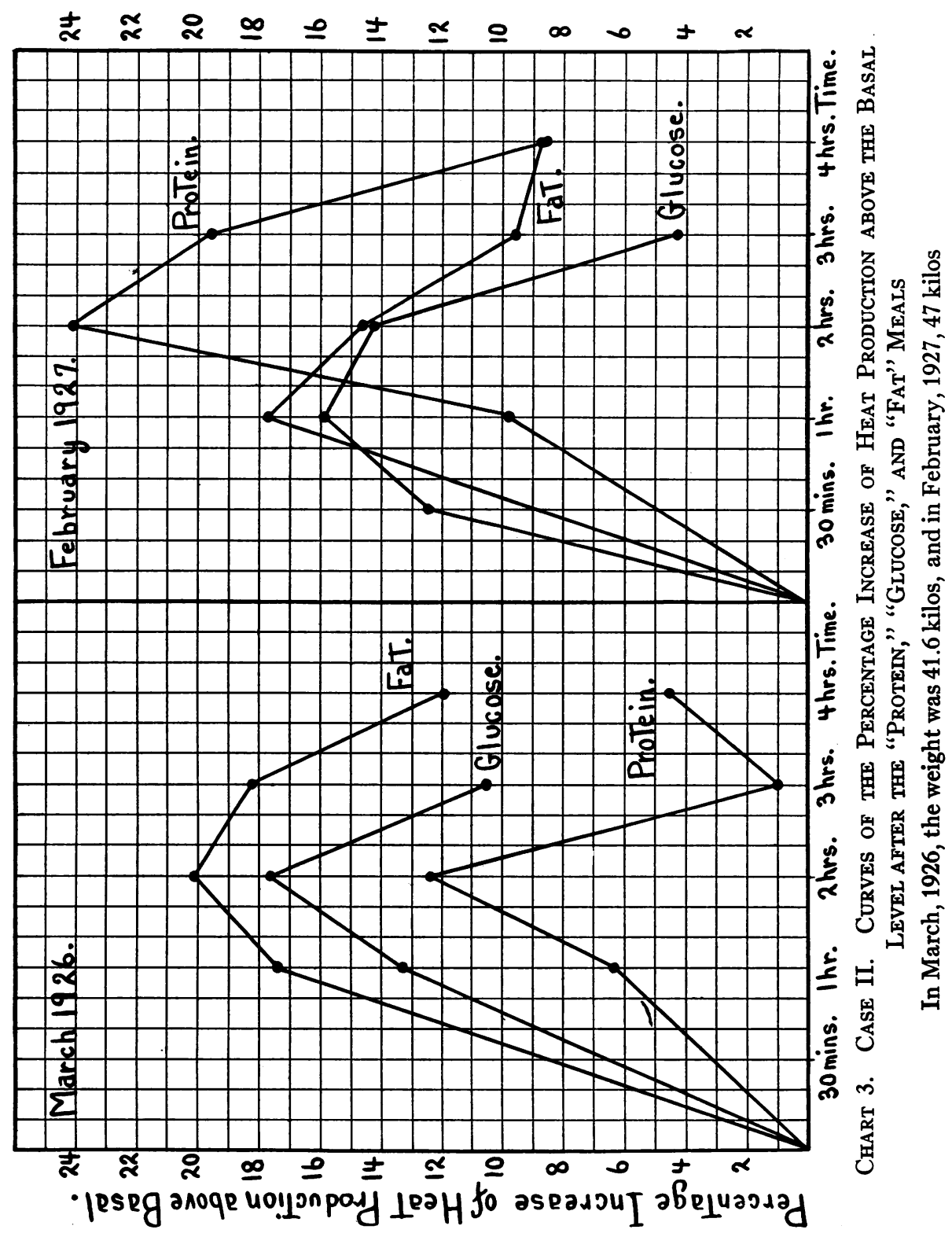

THE JOURNAL OF CLINICAL INVEGTIGATION, VOL. IV, NO. 3 
shown in table 5. In case II there was no elevation of the basal metabolism associated with a gain in weight of approximately 5 kilos, possibly explained by the coincident increase in height.

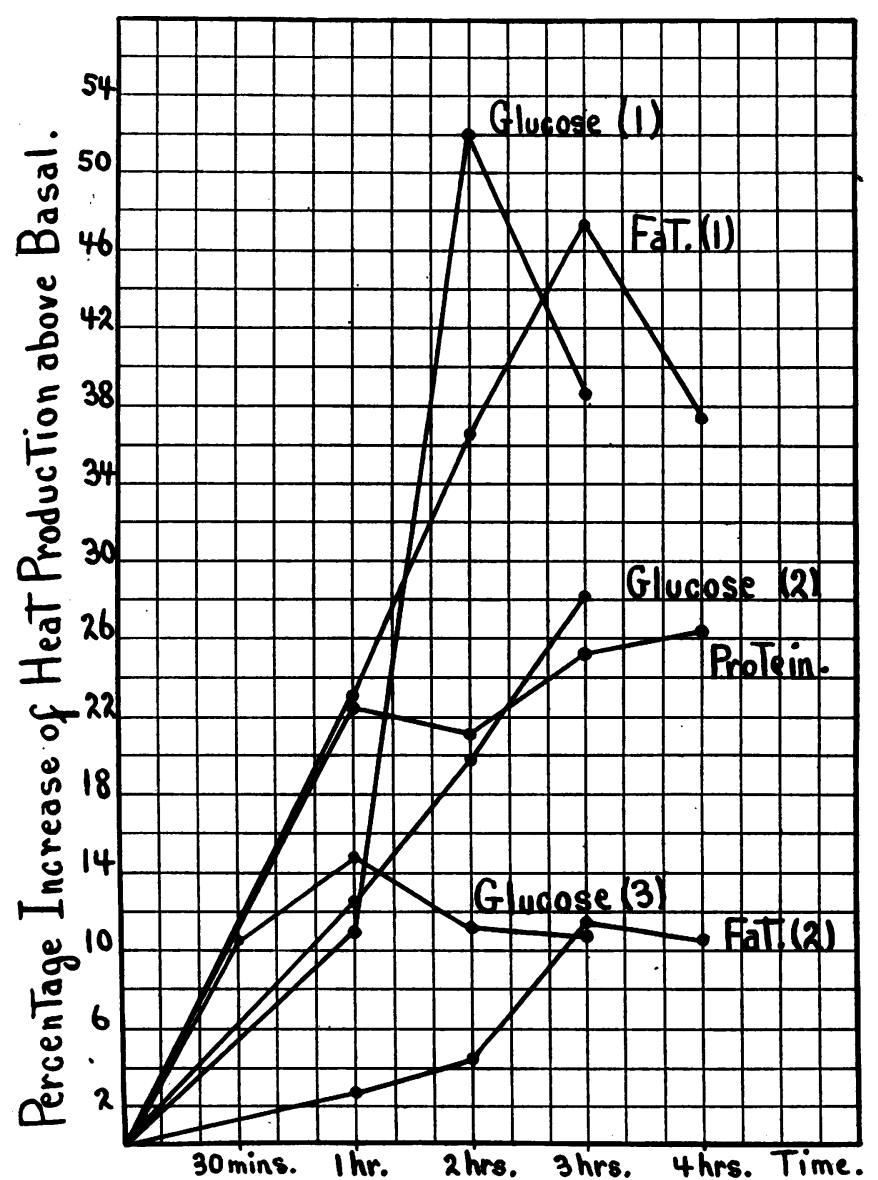

Chart 4. Case III. Curves of the Percentage Increase of Heat Production above the Basal Level after the "Protein," "Glucose," AND "FAT" MeALS

All experiments were done during one admission: see table 6 for details

Specific dynamic action of protein, glucose, and fat. In each case the specific dynamic action of protein, glucose and fat was determined. 
The details of the experimental periods were as already stated, and the results are recorded in table 6 . Graphs of the percentage increases of heat production are shown in charts 2 to 7 inclusive.

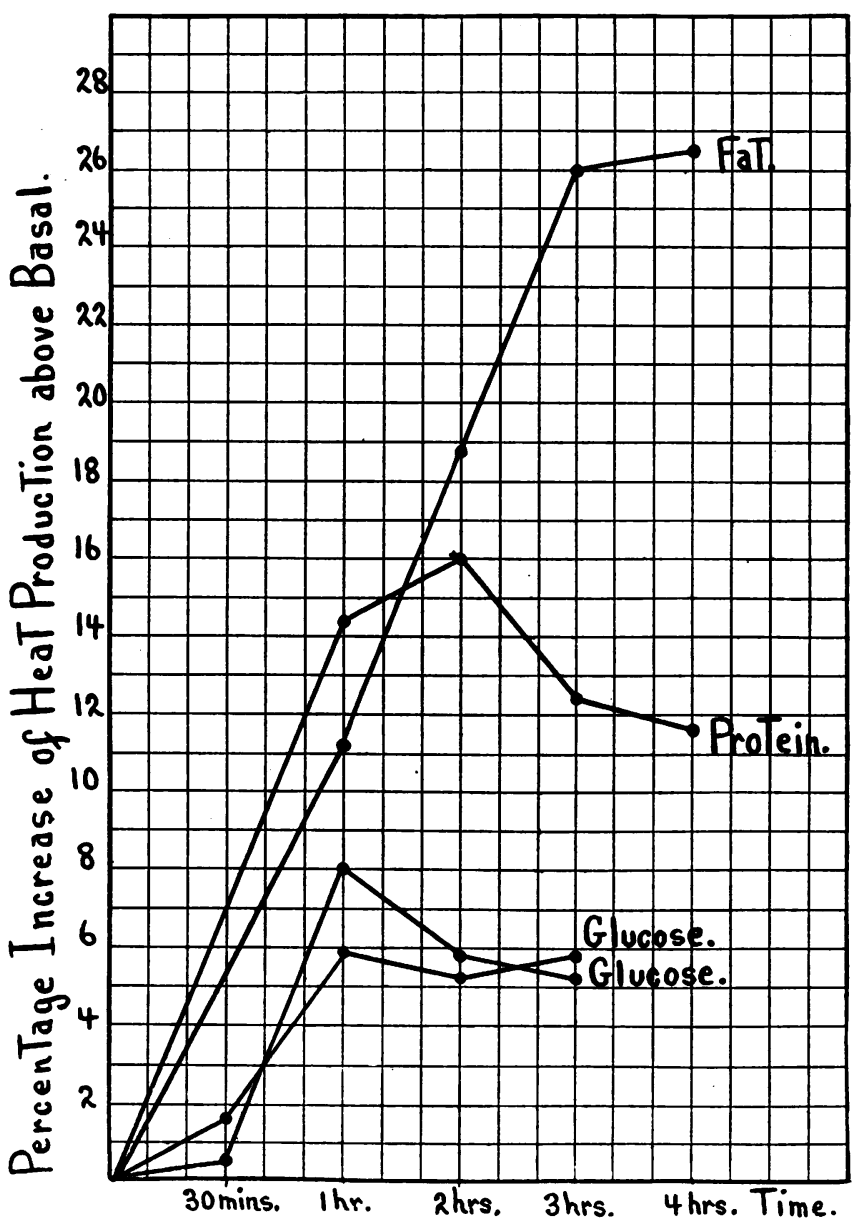

Chart 5. Case IV. Curves of the Percentage Increase of Heat Production above the Basal LeVel after the "Protein," "Glucose,"

$$
\text { AND "Fat" Meals }
$$

The two "glucose" experiments are duplicates

It will be noted that in the case of the "protein" meals only protein calories are recorded. These were obtained by calculation from an 
analysis of the nitrogen content of an aliquot sample of beef. The carbohydrate in the $60 \mathrm{cc}$. of lemon juice given with the glucose has been neglected. The total calories of the "fat" meals are tabulated. In the case of most of the "glucose" experiments expired air was collected at the end of 30 minutes and again at the end of 1 hour.

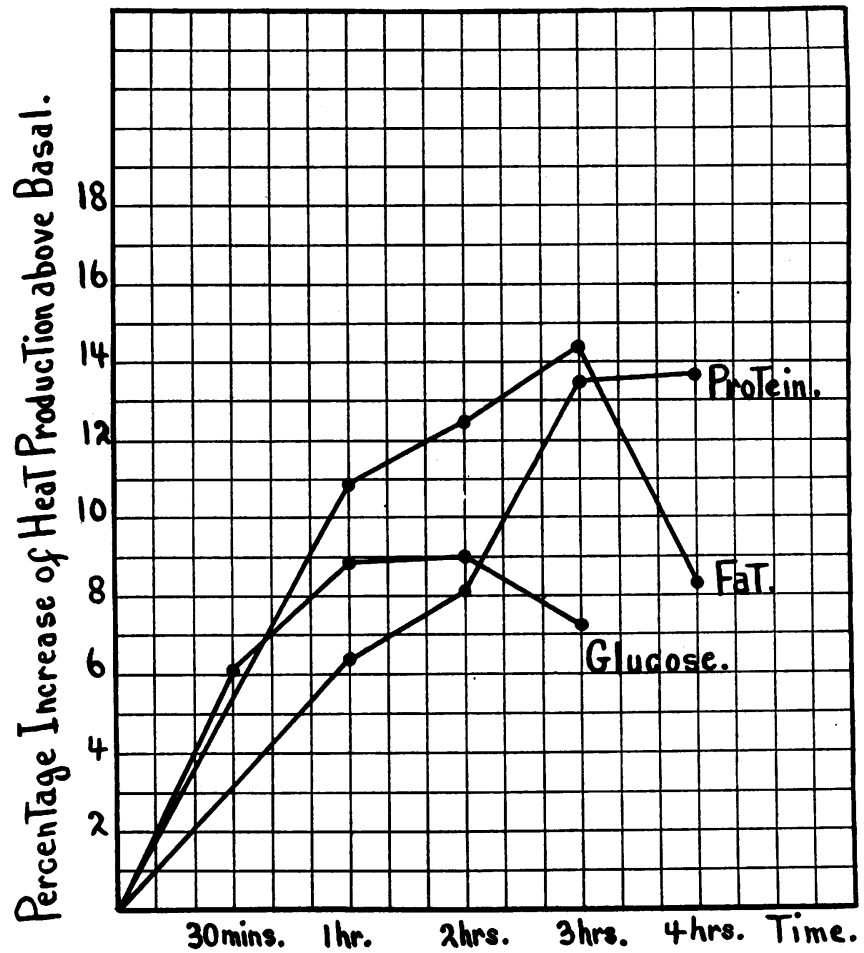

Chart 6. Case V. Curves of the Percentage Increase of Heat Production above the Basal Level after the "Protein," "Glucose," and "Fat" Meals

Calculations of each were completed on an hourly basis and accordingly the percentage increase of the heat production is so recorded. The actual caloric increase has been corrected for 30-minute periods. This also applies to the adrenalin experiment, case I, no. 5. Since the duration of the individual experiments was not sufficient in most instances for the elevated heat production to return to the 
basal level, the actual heat increase as recorded only applies to the period of observation. The relationship between the extra calories produced and the total calories ingested has been confined to the

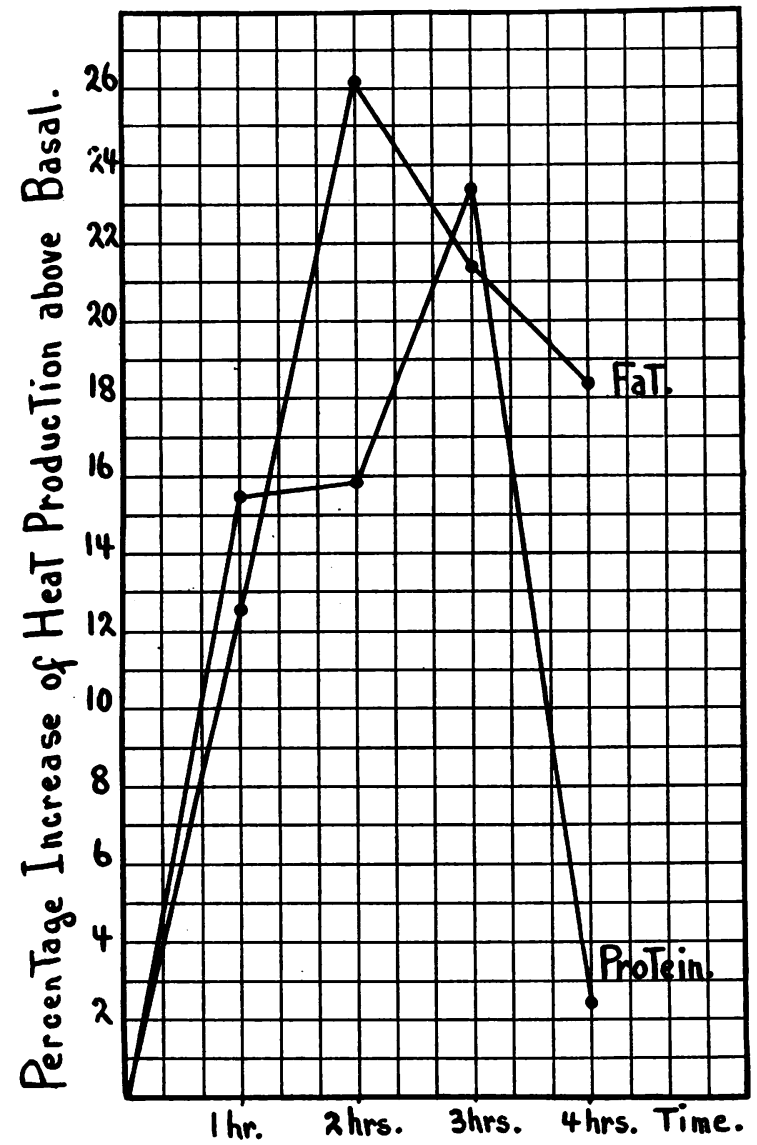

Chart 7. Case Vi. Curves of the Percentage Increase of Heat Production above the Basal LeVel after the "Protein" AND "FAT" MEALS

protein, glucose, and fat calories respectively. This was considered to be wise so as not to confuse results and in view of the fact that the "control" data was likewise calculated.

In an analysis of this data consideration must be given to the uni- 
formity of the basal level of heat production on different days as shown in comparable experiments.

\begin{tabular}{|c|c|c|}
\hline & & $\begin{array}{c}\text { Calories per square meter } \\
\text { per hour }\end{array}$ \\
\hline Case I. & Experiments 1 to 4 inclusive. . & . 28.4 to 29.0 \\
\hline Case I. & Experiments 6 to 8 inclusive. & 34.3 to 35.0 \\
\hline Case II. & Experiments 10 to 12 inclusive. & 38.4 to 40.0 \\
\hline Case II. & Experiments 13 to 15 inclusive. & 37.3 to 38.1 \\
\hline Case III. & Experiments 16 to 18 inclusive. & 26.2 to 26.9 \\
\hline Case IV. & Experiments 22 to 25 inclusive. & 26.9 to 28.6 \\
\hline Case V. & Experiments 26 to 28 inclusive. & 35.9 to 36.3 \\
\hline Case VI. & Experiments 29 to 30 inclusive & 42.9 to 43.8 \\
\hline
\end{tabular}

This constancy speaks for accuracy throughout the experimental periods.

Specific dynamic action of protein. The specific dynamic action of protein showed several marked variations from the "control" group. In the composite curve of the latter (chart 1) there was a progressive percentage increase in heat production reaching its maximum in the fourth hour. All the cases of undernutrition, except case V, showed a more rapid rise in heat production; in four, cases I, II, IV and VI, the maximum level being reached in the second or third hours. This was promptly followed by a notable drop, quite unlike the normal reaction. In cases II and $\mathrm{V}$ the percentage increase of heat production was below the normal throughout. In case I at the time of undernutrition, experiments 1 and 2, the percentage caloric increase was greater than in the controls, while after a normal level of nutrition had been extablished an identical observation gave a low normal result, experiment 6. A subsequent observation was also obtained on case II. With a weight of 41.36 kilos the percentage increase of heat production was definitely below the average normal result, experiment 10. Later, with a weight of 47.27 kilos, the maximum percentage increase of heat production was practically twice that previously obtained, experiment 13 . In both experiments the maximum elevation was obtained in the second hour, followed by a rapid drop. Of importance in the interpretation of experiments 10 and 13, case II, is the fact that coincident with a gain in weight from 41.36 to 47.27 kilos there was an increase in height of $7.9 \mathrm{~cm}$.

The actual extra calories produced in like periods of time averaged 
considerably less in the cases of undernutrition than in the "control" group. This is partly accounted for by the low basal level of the undernutrition cases and the fact that in four out of the six cases there was a premature sharp rise in heat production, to be followed by a rapid decline. In case I, calculating experiments 2 and 6 on a four hour basis, 3.95 fewer calories were produced after good nutrition had been established. Also, the relationship of the actual heat increase to the total ingested protein calories was slightly less in most instances than in the "control" group.

The specific dynamic action of glucose. In five of the cases experimental curves after like doses of glucose were obtained. In cases I, II, and III the curves were repeated with an improved state of nutrition: experiments $7,14,19$ and 20 . In four of the cases the maximum percentage increase of heat production was found at the end of the second hour as in the controls. Cases I, II and III all showed a higher percentage level of heat production than the average of the controls throughout the experimental periods of three hours. This was markedly so in cases I and III. In the latter the percentage increase of heat production amounted to 52.0 and 38.6 per cent in the second and third hours respectively.

In cases IV and $\mathrm{V}$ the percentage increase of heat production was much below the average in the controls. That the state of nutrition of the individual was an important factor is indicated from the findings in cases I and III. When the former weighed 31.36 kilos the percentage increase of heat production was much higher than in the controls, givng a total caloric increase in three hours of 20.22 calories: experiment 3. The same case, weight 40.45 kilos, showed very little specific dynamic action for glucose, the total caloric increase in a like experiment being only 6.28 calories in three hours, experiment 7 . In like manner case III, experiments 17,19 and 20 showed a decreasing total heat increase in identical experiments, namely, 34.44, 19.10, and 13.67 calories with an improving state of nutrition.

The percentage relationship between the ingested glucose calories and the total increment caloric increase was greater than in the average controls in cases I, II and III, and less in cases IV and V.

Specific dynamic action of fat. In five of the six cases the specific dynamic action of fat presented certain quite definite abnormalities. 
In all except case $\mathbf{V}$ the maximum percentage increase of heat production was much higher than in the average "control" group. This was very noticeable in cases I, III, IV and VI, where the maximum was $30.7,47.6,26.5$ and 26.2 per cent respectively. These results are comparable to the maximum in the "control" group of 15.9 per cent. In cases I, II and VI the rapidity of the rise of heat production was significant, the maximum percentage caloric increase being obtained in the second hour.

TABLE 7

Twenty-four-hour metabolism*

Case I

\begin{tabular}{|c|c|c|c|c|c|c|}
\hline Time & R.Q. & $\begin{array}{l}\text { Calories } \\
\text { per hour }\end{array}$ & $\begin{array}{l}\text { Calories } \\
\text { above } \\
\text { basal }\end{array}$ & $\begin{array}{c}\text { Calories } \\
\text { per square } \\
\text { meter } \\
\text { per hour }\end{array}$ & $\begin{array}{c}\text { Percentage } \\
\text { increase } \\
\text { above basal }\end{array}$ & Remarks \\
\hline 1926 & & & & & & \\
\hline January 25: & & & & & - & \\
\hline $\begin{array}{c}7 \text { to } 8 \text { a.m....... } \\
8.05 \text { a.m......... }\end{array}$ & 0.815 & 34.26 & & 30.5 & & $\begin{array}{l}\text { Basal hour } \\
\text { Breakfast }\end{array}$ \\
\hline 11 to $12 \mathrm{n} .$. & 0.808 & 42.25 & 7.99 & 37.6 & +23.2 & \\
\hline 12.05 p.m.. & & & & & & Dinner \\
\hline $\begin{array}{r}4 \text { to } 5 \text { p.m..... } \\
5.05 \text { p.m.......... }\end{array}$ & 0.827 & 43.81 & 9.55 & 39.0 & +27.8 & Supper \\
\hline 8 to 9 p.m... & 0.789 & 39.73 & 5.47 & 35.3 & +15.7 & \\
\hline January 26: & & & & & & \\
\hline 7 to 8 a.m. & 0.810 & 35.02 & 0.76 & 31.1 & +1.9 & Basal hour \\
\hline 8 to 9 a.m. & 0.856 & 34.92 & 0.66 & 31.0 & +1.6 & Basal hour \\
\hline
\end{tabular}

* Quiet in bed all the 25 hours.

Diet: Protein 56 grams, fat 118 grams, carbohydrate 150 grams.

One-third of total diet for each meal.

The total caloric increase in comparable 4-hour periods averaged much the same in the cases of undernutrition as in the controls. This was due to the lower basal level of the cases of undernutrition and the more rapid decrease in heat production after the maximum level had been attained. The percentage increase of heat production in relationship to the ingested fat calories was greater in cases I, II, III and VI than in the average "control" group.

In three cases, I, II and III, subsequent observations after an improvement in nutrition had taken place showed much less specific dynamic action for fat: experiments $8,9,15$ and 21 . 
Effect of adrenalin in case $I$. An observation after $0.5 \mathrm{mgm}$. of adrenalin, experiment 5 , gave a maximum percentage rise of heat production in thirty minutes of 20.0 , in one hour of 27.0 , falling practically to the basal level by the end of the second hour. These findings are quite comparable with the observations of Boothby and Sandiford (19) on the calorigenic action of adrenalin.

Twenty-four hour heat production in case I. Observations on the total heat production were made throughout twenty-four hours as shown in table 7. During this period the individual remained in bed, resting quietly most of the time. Three meals were eaten as stated. The basal level of heat production at the beginning and at the end of the period were almost identical. The maximum level of heat production was found four hours after dinner. A calculation of the total heat production above the basal level throughout the twenty-four hours showed that the individual expended 124.6 calories, which was 6.41 per cent of the total caloric intake of 1942 calories, 13 per cent of the total calories produced, or 15 per cent of the basal level of heat production.

\section{DISCUSSION}

The finding of abnormal specific dynamic action of the food factors associated with the development of marked states of undernutrition is considered to be of considerable significance. That the abnormality may disappear when a more normal level of nutrition has been attained would be indicated by the later observations in cases I, II and III. That this increased specific dynamic action for certain foodstuffs is the factor that causes the loss of weight might be indicated by the gain in weight following restriction of that food factor in the diet. (See case histories for details of diets.)

The fact that five of the cases ranged from 14 to 18 years of age is possibly of significance. Whether at this period in life, when the development of secondary sexual characteristics is active, some endocrine unbalance develops one can only suggest. That case II had certain findings characteristic of a future giant may be relevant. Also the well-known finding of Plaut (20) and others that the Fröhlich's type of obesity shows very little specific dynamic action for protein is suggestive. 
The low level of basal metabolism in the five cases where the undernutrition was associated with symptoms of ill health is considered to be due in part to the poor state of nutrition and in part to a compensatory mechanism that the body acquired to save heat under such circumstances. In cases I and III this was partly corrected with a gain in weight. In case II it remained unchanged but due to the gain in height associated with the gain in weight the general nutrition remained much the same.

The most marked abnormality seen in all cases except case $\mathrm{V}$ was the extraordinary rise in heat production after the "fat" meal. There was a much greater percentage rise than with the controls and the maximum level of heat production in three cases was attained at the end of the second hour. In two cases, cases I and III, this abnormality completely disappeared with an improved state of nutrition, and in case II it became appreciably less.

A comparison of the data of cases I, II and III, where subsequent like experiments were repeated after a gain in weight had taken place, failed to reveal any uniformity in the maximum level of heat production attained. That the state of nutrition can influence the specific dynamic action of protein was shown by McCann (21) in like experiments on a man at the end of a week's fast and after one week of normal diet. He observed that the maximum level of heat production was the same in the two observations.

\section{SUMMARY}

1. Six cases of undernutrition, five with and one without symptoms of ill health, are reported which show varying abnormalities of specific dynamic action for protein, glucose and fat. These abnormalities are compared with the findings in a "control" group of adult hospital patients.

2. The five cases in which the undernutrition was associated with symptoms presented basal metabolic rates varying from minus 15 to minus 31 per cent.

3. Regulation of food intake in accordance with the altered specific dynamic action resulted in a gain of weight in four cases. In the other" two sufficient time has not elapsed to make a definite statement. 
4. In cases I, II and III, coincident with a gain in weight, the abnormal findings with respect to specific dynamic action largely disappeared.

\section{CASE HISTORIES}

Case no. I. Hospital no. 43816

Present illness. F. N., a girl of 14 years was admitted to the Royal Victoria Hospital January 4, 1926. In her development there was nothing abnormal until July, 1925, when she began to lose weight associated with a loss of appetite. Due to unusual fatigue exercise was avoided. In November, 1925, she noticed that her hands and feet were cold, and constipation became troublesome.

A physician advised a high fat diet but upon eating such meals she noticed that her skin became warm and flushed for a period of about three hours. Loss of weight became progressively more marked, decreasing from 45.45 kilos in July, 1925, to 27.5 kilos upon admission.

Personal history. Birth was normal, the delivery being spontaneous. During infancy she was rather small but fat, and was breast-fed for twelve months. Throughout childhood she developed normally, being plump with "bright red cheeks" until the onset of the present trouble in July, 1925. She had measles and chicken pox as a child and menstruation began at twelve years of age. It was rather irregular for the first year and during the last three months has been absent. Mentally she was very bright, leading her class at school.

Physical examination. Height $146 \mathrm{~cm}$., weight 27.5 kilos, temperature, $97^{\circ} \mathrm{F}$., pulse, 76. The general appearance was that of a pale-skinned young girl who looked about two years older than her stated age. Her face and trunk were thin, the bony landmarks being prominent. There was little subcutaneous fat and the skin was of a dry texture. There was no edema. Both the lateral lobes and the isthmus of the thyroid gland were slightly enlarged, but of a soft uniform consistency. There was no evidence of increased vascularity. All the subcutaneous lymphatic glands were small, palpable, but not tender. The heart and lungs were normal. Blood pressure was systolic 90 and diastolic $60 \mathrm{~mm}$. Hg. The abdomen was negative. Both knee jerks were absent.

Special examinations. The urine showed no abnormalities. The red blood cells were 4,100,000 per cubic millimeter, whites 5,200 per cubic millimeter, and the hemoglobin was 75 per cent. The vital capacity was 100 per cent according to West's standards. The blood Wassermann was negative. X-ray examinations of the chest, skull, stomach, and duodenum showed no abnormalities. The fasting blood sugar was 0.08 per cent, rising after the ingestion of 100 grams of glucose in 30 minutes to 0.14 , in 60 minutes to 0.20 , and in 180 minutes to 0.18 per cent respectively. The basal metabolic rate remained relatively constant averaging minus 31.4 per cent (table 5).

Summary. The above physical and special examinations showed only an 
emaciated young girl with a dry skin and a slightly enlarged thyroid gland, low blood pressure, and absent knee jerks. The "glucose curve" showed possible evidence of delayed glycogen storage and the basal metabolic rate was markedly lowered. (See photograph taken January, 1926.)

Subsequent course of case. On the basis of the finding of a marked abnormality of the specific dynamic action for fat a diet rather low in that factor was given. The values were: protein 75 grams, fat 75 grams, and carbohydrate 250 grams, making 2030 calories. At the institution of this diet her weight was approximately 30 kilos. From then on there was a progressive gain; in February, 1926, 32 kilos, in April, 1926, 35 kilos, and in August, 1926, 40.5 kilos. In August, 1926, she was re-admitted for investigation.

Re-admission. Hospital no. 45395. The general state of nutrition was excellent (see photograph taken in August, 1926.) The skin was not dry, the thyroid gland was just palpable, the blood pressure was systolic 115 , and diastolic $78 \mathrm{~mm}$. Hg., and the knee jerks were active. Amenorrhea was still present. Rectal examination showed an infantile uterus. The basal metabolic rate averaged minus 18.2 per cent (table 5). A marked change in the patient's specific dynamic action for fat, glucose and protein had taken place (table 6 and chart 2).

Subsequently, in February, 1927, weight was found to be 42.5 kilos, the basal metabolic rate minus 19.3 per cent, and the specific dynamic action for fat definitely less than the average normal (table 6 and chart 2). There had been no change in height.

Since August 1926, an average normal diet has been eaten.

\section{Case no. II. Hospital no. 44374}

Present illness. M. S., a boy of 14 years was admitted to the Royal Victoria Hospital March 18, 1926. He was quite well up until two years previously when he began to grow rapidly. With the rapid growth he became weak, lost his appetite, and began to lose weight. The latter had amounted to 5.45 kilos at the time of admission. The personal and family histories were unimportant.

Physical examination. Height $169 \mathrm{~cm}$., weight 41.6 kilos, temperature $98^{\circ} \mathrm{F}$., pulse 80. Patient was a tall thin boy, both thighs showing horizontal striae due to stretching of the skin. The development of the secondary sexual characteristics was well marked. The heart and lungs were normal, with a blood pressure of systolic 98 and diastolic $64 \mathrm{~mm}$. $\mathrm{Hg}$. The basal metabolic rate averaged minus 14.2 per cent (table 5). An $\mathrm{x}$-ray of the skull showed the sella turcica to be larger than normal, but there was no evidence of any erosion of the bone. Further special examinations disclosed no abnormalities. The state of nutrition is well shown in the photograph taken upon admission.

Subsequent course of case. On the basis of the abnormal specific dynamic action for fat, a diet containing approximately 75 grams of protein, 75 grams of fat, and 250 grams of carbohydrate was given. By February, 1927, the weight had increased to 47.2 kilos and the height to $176.9 \mathrm{~cm}$. 
Re-admission. Hospital no. 46747. On February 20, 1927, he was re-admitted. The basal metabolic rate was minus 16.8 per cent. The specific dynamic action experiments were repeated. Due to the gain in height of $7.9 \mathrm{~cm}$., the general state of nutrition was about the same.

Case no. III. Hospital no. 44313

Present illness. A. O., a married woman of 31 years of age was admitted to the Royal Victoria Hospital March 12, 1926. She was quite well up until October, 1925, when she had an attack of jaundice associated with fever. After four weeks in bed the jaundice disappeared, but she remained weak, had no appetite, and began to lose weight. Food caused a sense of discomfort in her epigastrium. Weakness became very marked, confining her to bed for three months prior to admission. The loss of weight was approximately 23 kilos.

Personal history. Menstruation was regular up until October, 1925, but since then it had been absent.

Physical examination. Height $158 \mathrm{~cm}$., weight $34.1 \mathrm{kilos}$, temperature $98^{\circ} \mathrm{F}$., pulse 100. The picture was that of an extremely emaciated young woman, suffering from marked mental depression. A thorough examination including gastrointestinal, gall bladder, and liver function studies failed to account for her present state. There was slight epigastric tenderness and very slight motor delay in the stomach. The blood pressure was systolic 92 and diastolic $56 \mathrm{~mm}$., $\mathrm{Hg}$. The basal metabolic rate averaged minus 25.8 per cent. The photograph shows her state of nutrition.

Progress of case. In view of the abnormal rise in heat production after glucose and fat, a diet of protein 100 grams, fat 100 grams, and carbohydrate 150 grams was given. At first it was a continual struggle to get her to eat food, but with persistence a slight gain in weight commenced. By discharge on June 21, 1926, her weight had increased to $\mathbf{4 0}$ kilos and she had few complaints. With the gain in weight her mental attitude improved and she was up and about the ward each day. On June 17,1926, the basal metabolic rate was minus 17 per cent. Coincident with the gain in weight and the rising basal metabolism there was a great decrease in the abnormal rise in heat production after glucose and fat.

\section{Case no. IV. Hospital no. 44879}

Present illness. V. H., admitted to the Royal Victoria Hospital May 19, 1926, was a young woman of 18 years. Two years previously, when weighing 61.36 kilos, amenorrhea started. Shortly coldness of the hands and feet was noticed and constipation developed. Her skin became dry, weakness developed, and loss of weight was progressive. After eating, a dragging sensation developed in the epigastrium. By May, 1926, the loss of weight had amounted to 18 kilos.

Physical examination. Height $162 \mathrm{~cm}$., weight 43.8 kilos, temperature $98^{\circ} \mathrm{F}$., pulse 68 . The appearance was that of a greatly emaciated young woman. The skin was dry but not thickened, and the feet and hands were cold. The heart and 
lungs were normal. The blood pressure was systolic 100 and diastolic $65 \mathrm{~mm}$. $\mathrm{Hg}$. Further studies showed moderate visceroptosis and the basal metabolic rate averaged minus 26.6 per cent.

Progress of case. In accordance with the altered specific dynamic action findings a diet was given which contained 80 grams of protein, 75 grams of fat, and 240 grams of carbohydrate. For several months there was no gain in weight, but gradually she began to gain and in February, 1927 weighted 56.4 kilos. With the gain in weight all symptoms except moderate constipation disappeared. Menstruation recommenced in October, 1926.

\section{Case no. V. Hospital no. 46257}

Present illness. E. T., a girl of 15 years, was admitted to the Royal Victoria Hospital December 13, 1926. At the age of 12 years she weighted 72.72 kilos and menstruation commenced. Gradually she began to lose weight until December, 1925, her weight was 59.54 kilos. Shortly she became unusually tired, taking little exercise, and appetite became poor. In March, 1926, her weight was 62.27 kilos, in June, 1926, 59.54 kilos, in September, 1926, 54.54 kilos, and in October, 1926, 50.45 kilos. Upon admission it was 44.8 kilos.

Physical examination. Height $166 \mathrm{~cm}$., weight 44.8 kilos, temperature $97^{\circ} \mathrm{F}$., pulse 70. The appearance was that of an undernourished, pasty girl. The heart and lungs were negative and the blood pressure was systolic 110 and diastolic $60 \mathrm{~mm}$. Hg. The urine showed a trace of albumin when in the upright position which disappeared when lying down. A careful study of the renal function gave normal results. The basal metabolic rate averaged minus 15.1 per cent.

Progress of case. Due to the finding of an abnormal elevation of heat production after a "fat" meal she was given a diet containing only 1.5 grams of fat per kilo body weight, its total caloric content being equal to her theoretically normal basal metabolism plus 75 per cent. The values were protein 90 grams, fat 75 grams, and carbohydrate 390 grams. Her symptomatic improvement has not been very satisfactory. The weight has increased to 47.7 kilos (February 16, 1927). No further observations have been obtained.

\section{Case no. VI. Hospital no. 46328}

Present illness. B. R., a boy of 14 years, was admitted to the Royal Victoria Hospital, December 26, 1926. He had no symptomatic complaints but due to his state of undernutrition he was admitted for investigation.

Personal history. Patient was a full term baby and breast-fed for a few weeks only. Throughout infancy his nutrition was satisfactry. He had the usual children's diseases. Since about the age of eight has been thin and of a high strung temperament. He takes part in all games and stands well in school.

Physical examination. Height $149 \mathrm{~cm}$., weight 32.1 kilos. Although only a boy of 14 years the appearance was that of an older individual. The whole body was lean but well proportioned. The cheeks were hollow and wrinkled. The secondary sexual characteristics were not well developed. No organic abnormali- 
ties could be detected. The blood pressure was systolic 112 and diastolic $70 \mathrm{~mm}$. $\mathrm{Hg}$. The basal metabolic rate was minus 3.7 per cent. A photograph is appended.

Progress of the case. With the finding of a markedly increased specific dynamic action for fat, a diet was planned which contained 3 grams of protein and 2 grams of fat per kilo body weight, and enough calories to be equivalent to the theoretical basal plus 75 per cent. The values were protein 96 grams, fat 64 grams, and carbohydrate 350 grams. A verbal communication to date, February, 1927, stated that no gain in weight had taken place.

\section{BIBLIOGRAPHY}

1. Rubner, M., Die Gesetze des Energieverbrauchs bei der Ernährung, Leipzig, 1902.

2. Lusk, G., Jour. Biol. Chem., 1912-13, xiii, 27. Animal Calorimetry. III. Metabolism after the Ingestion of Dextrose and Fat, Including the Behavior of Water, Urea, and Sodium Chloride Solutions.

3. Lusk, G., Jour. Biol. Chem., 1912-13, xiii, 155. Animal Calorimetry. IV. The Influence of the Ingestion of Amino-acids upon Metabolism.

4. Lusk, G., Medicine, 1922, 1, 311. The Specific Dynamic Action of Various Food Factors.

5. Grafe, E., Deutsch. Arch. f. Klin. Med., 1915, cxviii, 1. Beiträge zur Kenntnis der Ursachen der spezifischdynamischen Wirkung der Eiweisskörper.

6. Atkinson, H. V., and Lusk, G., Jour. Biol. Chem., 1918, xxxvi, 415. Animal Calorimetry. XV. Further Experiments Relative to the Cause of the Specific Dynamic Action of Prote $n$.

7. Burge, W. E., and Neill, A. J., Amer. Jour. Physiol., 1918, xlvii, 13. Further Study on the Effect of Food in Increasing Oxidation.

8. Burge, W. E., Amer. Jour. Physiol., 1918, xlvii, 351. The Influence of the Ingestion of the Amino-acids, Adequate and Inadequate Proteins upon the Production of Catalase.

9. Burge, W. E., Amer. Jour. Physiol., 1919, xlviii, 133. The Reason for the Specific Dynamic Action of Protein.

10. Aub, J. C., Everett, M. R., and Fine, J., Amer. Jour. Physiol., 1927, lxxix, 559. The Intravenous Administration of Amino-acids to Decerebrate and Urethanized Cats.

11. Johansson, J. E., Skand. Archiv. für Physiol., 1909, xxi, 1. Untersuchungen über den Kohlehydratstoffwechsel.

12. Lusk, G., Jour. Biol. Chem., 1915, xx, 555. Animal Calorimetry. XI. An Investigation into the Causes of the Specific Dynamic Action of the Foodstuffs.

13. Lusk, G., Jour. Biol. Chem., 1924, lix, 41. Animal Calorimetry. XXIV. Analysis of the Oxidation of Mixtures of Carbohydrate and Fat. 
14. Benedict, F. G., and Carpenter, T. M., Pub. Carnegie Inst., Washington, No: 261. Food Ingestion and Energy Transformations with Special Reference to the Stimulating Effect of Nutrients.

15. Aub, J. C., and Du Bois, E. F., Arch. Int. Med., 1917, xix, 840. The Basal Metabolism of Dwarfs and Legless Men with Observations on the Specific Dynamic Action of Protein.

16. Gephart, F. C., and Du Bois, E. F., Arch. Int. Med., 1915, xv, 835: The Determination of the Basal Metabolism of Normal Men and the Effect of Food.

17. Magnus-Levy, A., Arch. f. d. ges. Physiol., 1894, lv, 1. Ueber die Grösse des respiratorischen Gaswechsels unter dem Einfluss der Nahrungsaufnahme.

18. Zuntz, N., and von Mering, Arch. f. d. ges. Physiol., 1883, xxxii, 173. Inwiefern beeinflusst Nahrungszufuhr die thierischen Oxydationsprocesse?

19. Boothby, W. M., and Sandiford, I., Amer. Jour. Physiol., 1923, Ixvi, 93. The Calorigenic Action of Adrenalin Chlorid.

20. Plaut, R., Deutsch. Arch. f. Klin. Med., 1922, cxxxix, 285. Gaswechselsuntersuchungen bei Fettsucht und Hypophysiserkrankungen.

21. McCann, W. S., Proc. Soc. Exp. Med. and Biol., 1919-1920, xvii, 173. An Observation of the Effect of a Protein Meal Given to a Man at the End of an 8-day Fast. 


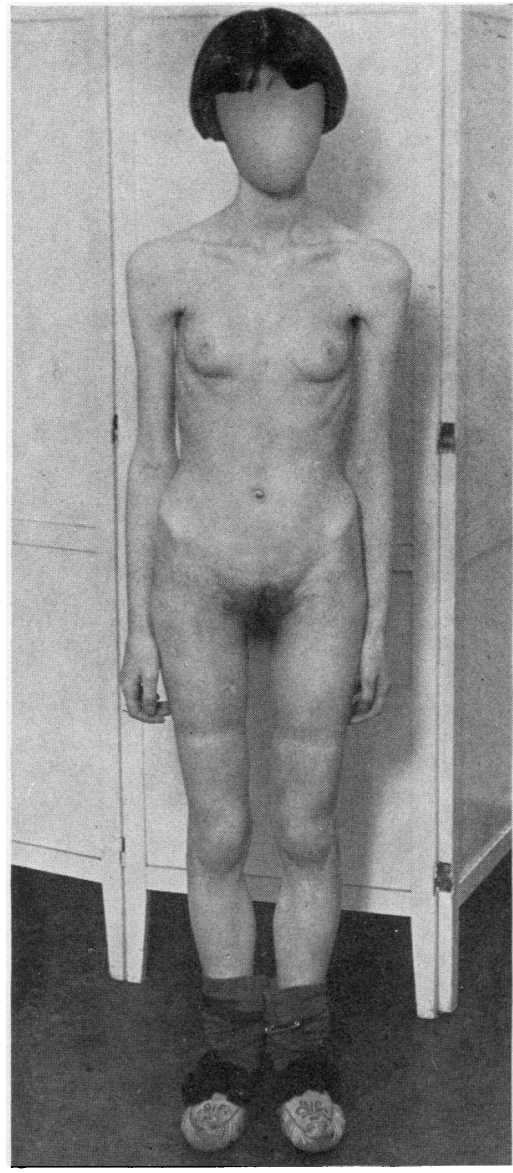

FIG. 1

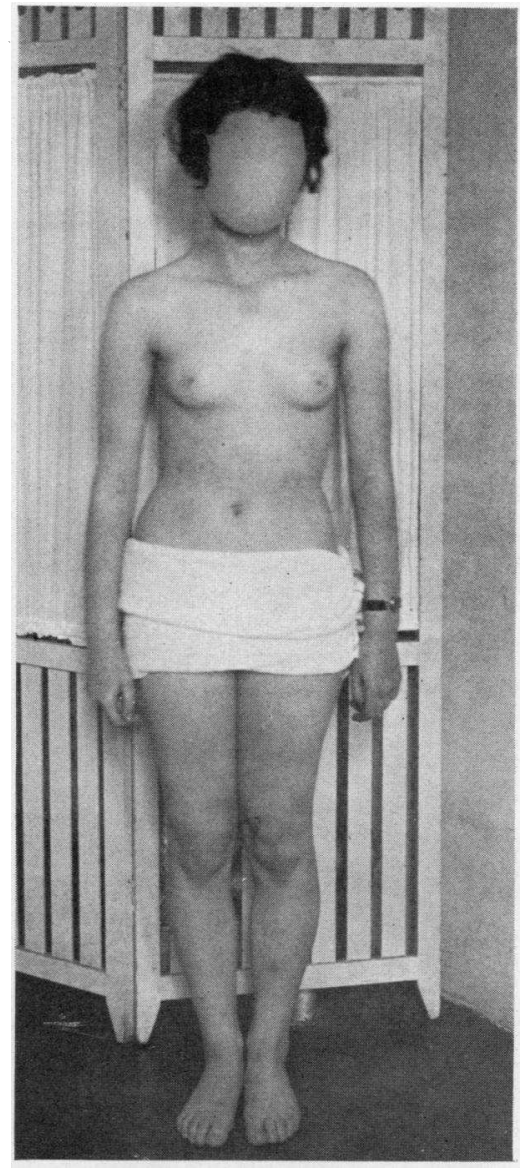

FIG. 2

Fig. 1. Case I. January, 1926. Weight 27.5 Kilos

Fig. 2. Case I. August, 1926. Weight 40.45 Kilos 


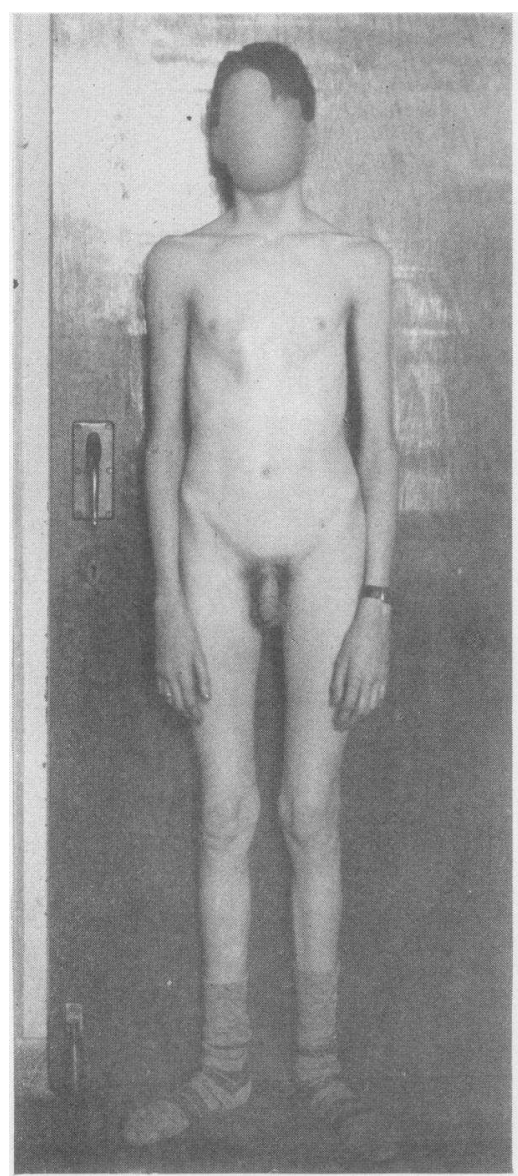

FIG. 3

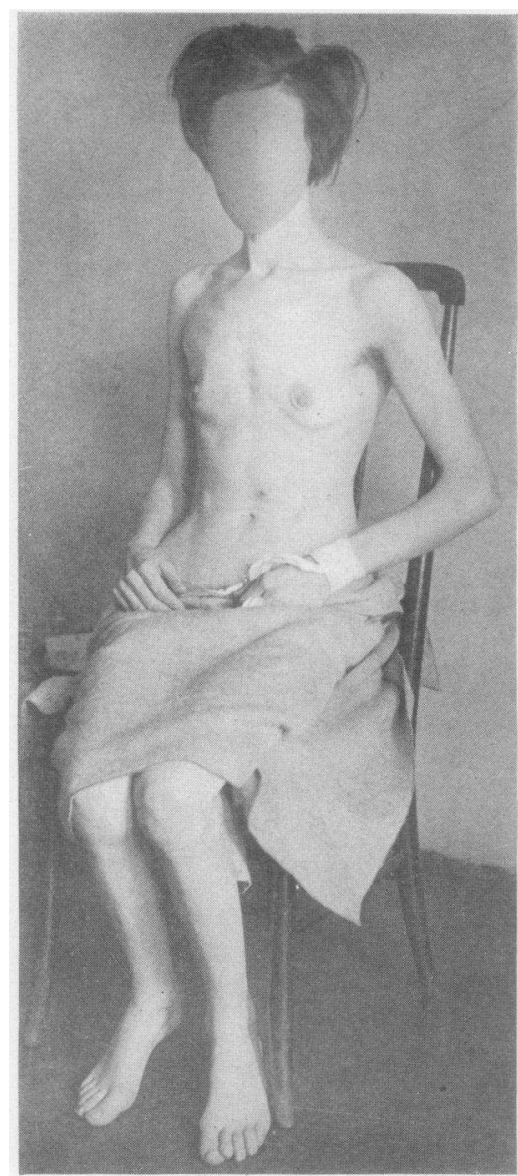

FIG. 4

Fig. 3. Case II. March, 1926. IVeight 41.6 Kilos

Fig. 4. Case III. April, 1926. Weight 34.1 Kilos 


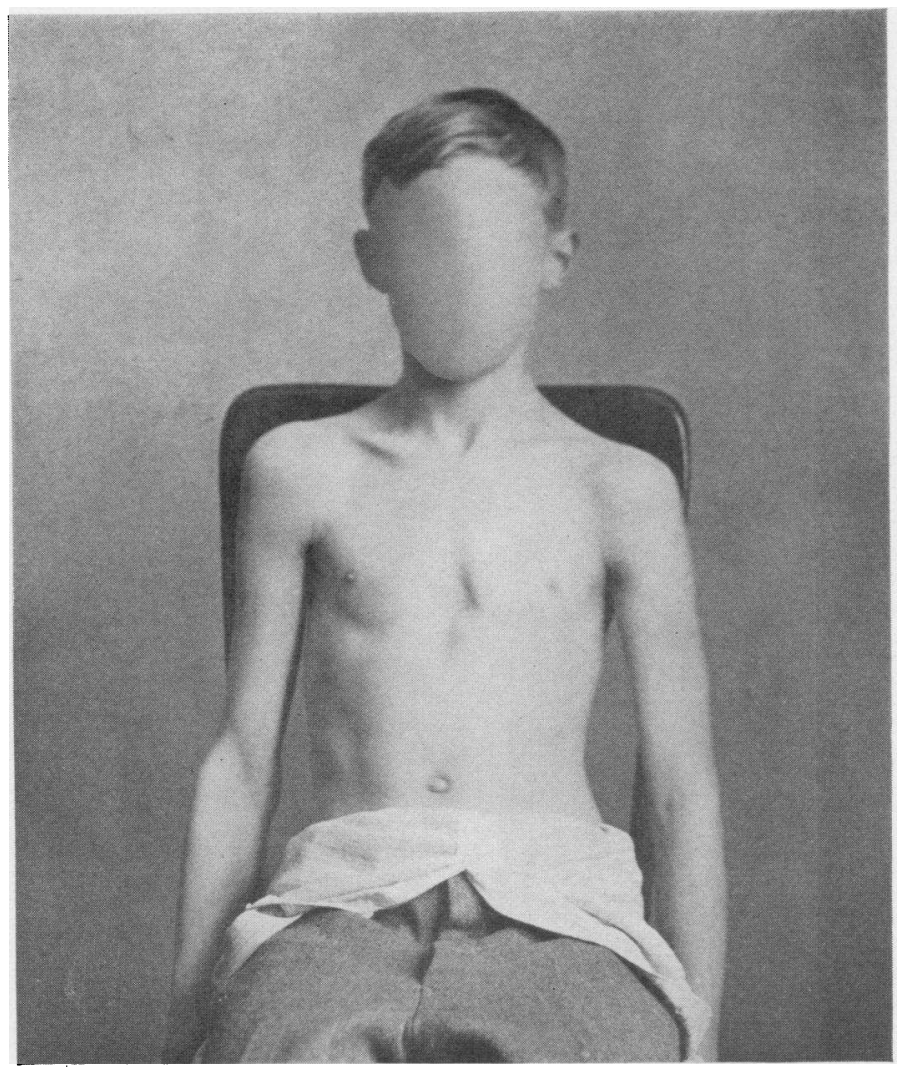

Fig. 5. Case Vi. Decenber, 1926. Weight 32.1 Kilos 